\title{
Integrating Moodle-Based of Communicative Language Teaching In Higher Education
}

\author{
Rizky Eka Prasetya ${ }^{1}$ \\ ${ }^{I}$ Akademi Sekretari Budi Luhur, Jakarta, Indonesia
}

\section{A R T I C L E I N F O}

Article history:

Received January 18, 2021

Revised January 27, 2021

Accepted April 20, 2021

Available online May 25, 2021

Kata Kunci:

Moodle, Komunikatif, Instruksi

Berbasis Konten

Keywords:

Moodle, Communicative,

Content-Based Instruction

DOI:

http://dx.doi.org/10.23887/jpbi.v9 i1.31265

\section{A B S T R A C T}

\begin{abstract}
A B S T R A K
Ketidakmampuan beradaptasi dan penyesuaian dalam pengajaran bahasa Inggris berbasis Moodle khususnya pengajaran bahasa komunikatif. Penelitian ini bertujuan untuk menganalisis pendekatan pengajaran Bahasa Komunikatif yang digunakan dalam pengajaran Bahasa Inggris berbasis Moodle di Perguruan Tinggi. Desain penelitian yang digunakan adalah pendekatan kualitatif dengan desain penelitian eksperimen sekuensial dan menggunakan wawancara semi terstruktur. Subyek penelitian adalah 12 dosen bahasa Inggris. Hasil penelitian menunjukkan bahwa pembelajaran bahasa komunikatif pendekatan berbasis proses mengadaptasi dan mengadaptasi pengajaran bahasa Inggris berbasis Moodle. Praktik yang berkaitan dengan pengetahuan dan pengalaman dosen melakukan pengajaran bahasa Inggris di Moodle. Studi ini menyimpulkan bahwa pendekatan pengajaran bahasa komunikatif berbasis Moodle pedagogis harus ditingkatkan, dan sistem memberikan kemungkinan yang luar biasa. Moodle melakukan penyesuaian dalam pendekatan pedagogis bahasa Inggris, dan secara berurutan mengembangkan produktivitas belajar dan mengajar. Implikasi penelitiannya adalah membuat penyesuaian dalam pendekatan pedagogis bahasa Inggris, dan mengembangkan produktivitas pembelajaran dengan mengintegrasikan ke komputer dan Internet.
\end{abstract}

Inability to adapt and adjust in Moodle-based English teaching, especially communicative language teaching. This study aims to analyze the Communicative Language teaching approach used in Moodle-based English teaching in universities. The research design used is a qualitative approach with a sequential experimental research design and using semi-structured interviews. The research subjects were 12 English lecturers. The study results indicate that the process-based approach to communicative language learning adapts and adapts Moodle-based English teaching. Practices related to the knowledge and experience of lecturers in teaching English at Moodle. The study concludes that the pedagogical Moodle-based communicative language teaching approach should be improved, and the system provides tremendous possibilities. Moodle makes adjustments in its English pedagogical approach and sequentially develops teaching and learning productivity. The implication of the research is to make adjustments in the pedagogical approach of English and develop learning productivity by integrating it into computers and the Internet.

This is an open access article under the CC BY-SA license. Copyright (C) 2021 by Author. Published by Universitas Pendidikan Ganesha.

\section{INTRODUCTION}

The integrating of technology has been introduced, and mobile devices, similar to smartphones and tablets, have become a part of teaching besides computers (Chen \& Tsai, 2021; Sprenger \& Schwaninger, 2021). A common concept in practice in language learning is computer-assisted language learning (CALL). On the other hand, Integrative CALL transforms to a viewpoint that unifies different abilities (listening, speaking, reading, and writing) and more thoroughly toward the language learning process. In integrative approaches, students discover to utilize various technological instruments as an open-ended language learning process (Başöz \& Çubukçu, 2014; Huseyin et al., 2015). There are three classifications of CALL criteria: 1) computer-supported classroom teaching, 2) hybrid teaching, and 3) utterly online course, long-distance or local (Hashemi \& Aziznezhad, 2011; Mahmoudi et al., 2012). Current technologies do not solely accept new teaching or learning paradigms. They further improve new models. The very presence of networked computers generates opportunities for a new model of communication. a pedagogy of networked computers is necessary, therefore, to get a comprehensive outlook (Novrianti, 2014; Wang et al., 2018). It is considering the purpose of information technology in language learning and the role of language learning in society.

Today's technology can be used by lecturers for online learning. This e-learning platform provides users with a series of communication facilities, such as forums, chat and message systems, wiki space, etcetera (Alavudeen et al., 2021; Shetu et al., 2021). Employing forums, we can communicate in a synchronized method, enabling students to interact with their friends or their lecturers at any moment, implemented an Internet 
connection exists. The forum discussions can be compared to usual interest topics or focused on a particular topic, where any user can open a discussion (Kyewski \& Krämer, 2018; Valverde-Berrocoso et al., 2020). Unlike a forum, the Chat feature gives synchronized, real-time communication within the course platform's users. In Moodle, the wiki is a range where students can create collaborative exercises (Fatmawati, 2019; Nugroho \& Iqbal Arrosyad, 2020). It can be accepted in a seminar or project in the model for being practiced in groups. The student-centered program establishes the learner at the center of the electronic learning process. It addresses the learning more meaningful, applicable, and engaging by changing focus on the particular students and their requirements. While producing a course, we frequently disregard the essence of a student-centered perspective. The English teaching needs interactive communication to engage the participants using their foreign language (English) (Sadeghi \& Sadeghi, 2012; Sirivedin et al., 2018). The principles were adopted and affirmed in communicative language teaching.

In the students' centered course, the lecturer can practice the Communicative Language Teaching (CLT) and student-centered integrating entirely with each additional in English language teaching. The communicative approach has been comprehensively realized because It represents the management of highly inclusive principles educated in communicative competence as the purpose of second and foreign language teaching (Sokolova et al., 2018; Usmanova et al., 2015). Communicative outline and methodology as the process of accomplishing this object, communicative language teaching has developed as our understanding of second language learning processes. Modern communicative language teaching principles and application hence brings on numerous distinct educational standards and customs (Macaro \& Tian, 2015; Sadeghi \& Sadeghi, 2012). Moreover, considered that it represents several diverse causes (Khotimah et al., 2019; Wei et al., 2018). There is no individual or agreed-upon set of methods that identify modern communicative language teaching. Instead, today's communicative language teaching refers to a mechanism of generally agreed-upon principles applied differently, determined on the teaching circumstances, the learners' age, students' proficiency level, their learning aims, and etcetera.

The previous research carried an identification, administration, and implementation to the Moodle in English teaching and learning (Butova et al., 2019; Chang \& Lan, 2019; Yafaei \& Attamimi, 2019). Nevertheless, insignificant confirmation of importance might be incorporated in the particular contexts of CLT and LMS Moodle. The Moodle course allows the teacher, instructor, or lecturer to preserve significant time to concentrate on communicative assignments (Aikina et al., 2020; Herayanti et al., 2017). The conclusions of her study had different functional indications in English teaching Moodle-based courses development. Based on the previous finding study, teaching English Moodle-based has become significant to discovered in the pandemic these days. Most English lecturers are reliant on the Moodle system to facilitate distance teaching or learning. Therefore, the study was principally designated to investigate the applicable CLT in Moodle-based and determine the feature of every e-learning activity LMS Moodle online learning environment. This study aims to analyze the Communicative Language teaching approach used in Moodle-based English teaching in universities.

\section{METHOD}

The study was conducted in the qualitative approach experimental sequential research design. Qualitative survey research refers to a flawed structured research methodology to gain in-depth information about the lecturer's fundamental knowledge, perspective, and justification. The study utilized a semi-structured interview. It was conducted the depth interviewing of the respondent by convenient circumstances. The tangible research devices applied in the study composed focused on questionnaires and interviews. The questionnaire was formed to investigate the lecturer's adapted Moodle in their communicative language teaching. It is presumed to recognize the employing feature, accommodating virtual class in LMS Moodle, developing their online teaching experiences. Two components of the questionnaires concentrated on the lecturer's background knowledge in English language teaching at higher education and attempted to explore Moodle's practice.

\section{RESULT AND DISCUSSION}

\section{Result}

CLT or Communicative Language Teaching implies the pedagogical approach for teaching foreign or second languages that emphasizes interaction to happen the centers and terminal object of learning a language (Gong et al., 2018; Ho, 2020). The representation of eLearning classroom activities referred to new functions for lecturers and learners. Learners had to engage in classroom activities based on a collaborative rather than an individualistic approach (Dewi et al., 2018). They should enhance convenient listening to their peers in a group or pair activity tasks, preferably relying on the lecturer for the model. The process-based methodologies referred to creating an eLearning process to facilitate language teaching and learning. These approaches implied contentbased instruction and task-based instruction. Content-based instruction concentrated on the appropriate pedagogical component by using content as the English Moodle course's driving capability. The activities linked 
and matched all the different communicative competence dimensions (listening, speaking, writing, and reading) presented in Table 1.

Table 1. Process Content-Based CLT Approach Moodle

\begin{tabular}{ll}
\hline \multicolumn{1}{c}{ Content-Based Moodle Instruction } & \multicolumn{1}{c}{ Moodle Features } \\
\hline & Internal Email \\
Participants' Interactivity & Forums or Chats \\
& Notes \\
& Upcoming Events \\
& Information Channels \\
& Multi-page content on lesson feature \\
Codesign the Moodle Course & Forums or Chats \\
& Notes \\
& Glossary \\
& Lesson \\
Formulating significant interaction & Feedback Comment Assignment Feature \\
& Forums or Chats \\
& Wiki \\
Feedback centered & Survey \\
& Feedback Activity \\
Reproduce Target Language & Feedback Assignment or quiz \\
& Forums or Chats \\
& Notes \\
Learner needs & Glossary \\
& Lesson \\
the comprehensible structure of the language aspects & Forums or Chats \\
& Wiki \\
\hline
\end{tabular}

Task-based instruction is mainly designed for classroom tasks. The Moodle-based integration is intended to require distinct interactional strategies and could potentially also require specific language standards. It covered the competence in grammatical, sociolinguistics, discourse, and strategy. Well-known e-learning activities do not designate similar tasks as English teaching Moodle-based, presented in Table 2.

Table 2. Process Task-Based CLT Approach Moodle

\begin{tabular}{ll}
\hline \multicolumn{1}{c}{ Task-Based Moodle Instruction } & \multicolumn{1}{c}{ Moodle Features } \\
\hline & Internal Email \\
Non-Isolated Environment & Forums or Chats \\
& Information Channels \\
& Resources (Book, File, Folder, Label, Page, URL) \\
Attractive Material & Glossary \\
& Lesson \\
& External tool \\
& Resources (Book, File, Folder, Label, Page, URL) \\
Actuality material & Wiki \\
& Survey \\
& Lesson \\
Completed Competency Object & Wiki \\
& Survey \\
Sharing ideas & Lesson \\
& Assignment and quiz \\
& Forums or Chats \\
& Notes
\end{tabular}




\begin{tabular}{ll} 
& Glossary \\
& Lesson \\
Distinctive assessment and testing & Assignment or Quiz \\
& Forums or Chats \\
Involve learner extra & Course Management \\
& Choice \\
\hline
\end{tabular}

Moodle-based class language involves content, including a grammar section, a reading section, or any other content. The concept has to be the channel that accommodates the activities or assessments synchronically, but in the face-to-face meeting approaches to language teaching, content is decided following other decisions that have been given.

"Our Moodle class has designed to be more communicative approach as synchronous as possible in the electronic environment." (Respondent 08)

Practical eLearning needs cooperation and collaboration from the learner (Chang \& Lan, 2019; Li et al., 2018). Teachers are continually looking to advantage technology to support their purposes and generate a Moodle English course environment conducive to interactive learning (Aris et al., 2019; Sorensen, 2013). Communication is eminent for English pedagogical to happen. Lecturer interacts with their students through forums, chat, and editing texts throughout online collaboration in the Moodle feature. Chat enables lecturers and students to communicate concerning a synergetic task, participate in ideas, assign links, and work together on outlines. The feature of live chats can be logged and gathered for future reference (Effendi \& Hendriyani, 2020; Mohd Kasim \& Khalid, 2016).

"I change my position to the co-learning; the situation is to prevent the uncomfortable Moodle class." (Respondent 11)

The position of the lecturer is evolving in lively and useful learning methodologies. The lecturer acts as a facilitator in eLearning (Müller et al., 2021; Wu \& Wu, 2020). Teaching and learning are comprising transformed due to innovations in the pedagogical environment. Creating an e-learning situation and learning practices that support students in converting engaged participants create their understanding and skill effect (Kristanto et al., 2017; Nácher et al., 2021). It means the facilitator needs to ignite students' interest and curiosity, involve them through technology integration, and work as mentors to supervise them.

"Feedback is essential for my students in Moodle so that they can get full information related to their ability." (Respondent 09)

The feedback Moodle-based could implement to several English Moodle circumstances and procedures. The feature refers to a variety of techniques employed by lecturers, and the function is to facilitate responses from the students to an activity or assignment. Moodle exercise activities offer numerous distinct forms of feedback. Feedback is requiring of the learner (Mohd Kasim \& Khalid, 2016; Sorensen, 2013). Learners need to compare the different sections of feedback upon each other, the principles, point, seldom to a model response, and the determinations they proceeded with their work.

"Our coverage materials were complex between speaking, writing, listening, and reading. This is essential to have a communicative approach." (Respondent 06)

LMS Moodle gains recognition in Higher Education as an application that can accommodate self-learning and revitalize both the students and the teachers to be connected (Ramkissoon et al., 2020; Wu \& Wu, 2020). Moodle provides many different kinds of content forms to be uploaded and convenient for students and lecturers. Moodle supports learning to be completed online or at a distance. Moreover, it allows resources to be available to students in the instructor-guided course. Moodle also has complex possibilities and instruments available for application. The system supports communication between the instructor and students, and students can also interact with each other (Fatmawati, 2019; Nugroho \& Iqbal Arrosyad, 2020).

\section{Discussion}

Moodle task-based instruction indicates linguistic performance rather than linguistic competence. The purpose of teaching a foreign language implies the real practice of language in actual conditions. Linguistic competence is recognized similarly involved with the implicit principles of language structure. So that the common knowledge is not intentional or available for the spontaneous outline but fundamentally absolute in the ideal speaker-listener can maintain (Garbin et al., 2020; Mitra et al., 2021). Peer review is a useful pedagogical English learning in higher education (Sarfraz et al., 2015; Sokolova et al., 2018). This schema signifies a collaborative learning approach in which students evaluate and review each other's practice. In Moodle cases, students contribute feedback on the essence of their peer's practice, and the process may be improved (Butova et al., 2019; Zabolotniaia et al., 2020). The Moodle LMS performs an excellent function of establishing this effective learning strategy using the Workshop activity feature. This student-focused mechanism enables 
students to propose tasks and be selected others' work for review and assessment developed on the teacher's criteria compensation.

Teaching materials form an essential component of most English teaching Moodle-based. It included textbooks, videos, and images to the course, and lecturers depend gradually on various materials to support their teaching and students' learning. However, many lecturers proceed to create their materials for electronic classroom applications (Chang \& Lan, 2019; Yafaei \& Attamimi, 2019). Moodle implements an effortless process for a facilitator to present materials to the students. These materials might utilize the form of files such as word-operating documents or slide presentations. The materials can be arranged on the course either as personal items or pack up collectively inside folders (Prihandoko et al., 2017; Yilmaz \& Korur, 2021).

The authentic material equals the specified material composed in English that was not designed for meditated practice in the English language Moodle-based. Applying this content to prepare English teaching can obtain the learning process more appealing, creative, and stimulating. It can also be beneficial to evoke positive responses from learners (Febliza \& Okatariani, 2020; Herayanti et al., 2017). A Moodle resource is a feature that a lecturer may apply to assist learning, similar to a link or a file. Moodle supports a comprehensive design of resource classification that lecturers may combine with the courses (Fatmawati, 2019; Zabolotniaia et al., 2020). In the edit form, the lecturers may attach different sources completed in the drop-down menu, and also appears as the link, which has a picture in front of it, describing the variety of resources. Grammar in function has a definite center on the text's circumstances being examined, emphasizing how language is applied to expose meaning (Lin et al. 2020). Since functional grammar is revealed, the real world's context might be classified into several elements. Teaching Moodle-based can transform the pedagogical approaches to student-centered, concentrating on encouraging linguistic sensitivity and developing listening knowledge and expression to allow students to master English as promptly as conceivable. Foreign Language acquisition does not rely on grammar and indefensible exercises but student's constant usage.

\section{CONCLUSION}

The pedagogical Moodle-based communicative language teaching approach has to be improved, and the system provides an outstanding possibility. Moodle makes adjustments in English pedagogical approaches and sequentially develops teaching and learning productivity with the cooperation of computers and the Internet. Content-based instruction has a central issue. The extent to which concentrating on content provides an adequate foundation for the improvement of language skills. Lecturers often find it challenging to accommodate this approach because Moodle needs to be continuously implemented. Task-Based Approach issues appear in implementing English Moodle-based teaching. Principles for selecting and progressing tasks are also unsettled. Content issues are also of inconsiderable consequence in Task-Based Instruction, delivering limited significance to those involved with Moodle-based teaching.

\section{REFERENCES}

Aikina, T. Y., Mikhailovna, L., \& Bolsunovskaya. (2020). Moodle-Based Learning: Motivating and Demotivating Factors. International Journal of Emerging Technologies in Learning (IJET), 15(2). https://onlinejour.journals.publicknowledgeproject.org/index.php/i-jet/article/view/11297

Alavudeen, S. S., Easwaran, V., Mir, J. I., Shahrani, S. M., Ahmed Mohammed Almodeer Aseeri, A. A., Khan, N. A., \& Asiri, A. A. (2021). The influence of COVID-19 related psychological and demographic variables on the effectiveness of e-learning among health care students in the southern region of Saudi Arabia. Saudi Pharmaceutical Journal. https://doi.org/10.1016/j.jsps.2021.05.009

Aris, B., Ardian, A., \& Ferry, M. (2019). Pengembangan Media Pembelajaran Berbasis E-Learning Pada SMK di Pontianak. Jurnal Nasional Komputasi Dan Teknologi Informasi (JNKTI), 2(2), 133. https://doi.org/10.32672/jnkti.v2i2.1556

Başöz, T., \& Çubukçu, F. (2014). Pre-service EFL Teacher's Attitudes towards Computer Assisted Language Learning (CALL). Procedia - Social and Behavioral Sciences, 115. https://doi.org/10.1016/j.sbspro.2014.01.253

Butova, Dubskikh, A., Kisel, O. V., \& Chigintseva, E. (2019). Electronic educational environment Moodle in English language training. Arab World English Journal (AWEJ), 10. https://doi.org/10.24093/awej/vol10no1.4

Chang, M. M., \& Lan, S. W. (2019). Exploring undergraduate EFL students' perceptions and experiences of a Moodle-based reciprocal teaching application. Open Learning: The Journal of Open, Distance and eLearning. https://doi.org/10.1080/02680513.2019.1708298

Chen, C.-H., \& Tsai, C.-C. (2021). In-service teachers' conceptions of mobile technology-integrated instruction: Tendency towards student-centered learning. Computers \& Education, 170(1). 
https://doi.org/10.1016/j.compedu.2021.104224

Dewi, N. W. I. S., Suarsana, I. M., \& Suryawan, I. P. P. (2018). Pengaruh Model Pembelajaran Kolaboratif Berbantuan Masalah Autentik Terhadap Kemampuan Pemecahan Masalah Matematika. Jurnal Matematika, Sains, Dan Pembelajarannya Universitas Pendidikan Ganesha, 12(1), $26-41$. https://doi.org/10.30998/jkpm.v2i2.2495

Effendi, H., \& Hendriyani, Y. (2020). The Conceptual and Hypothetical Model of Interactive Blended Problem Based Learning. JPI (Jurnal Pendidikan Indonesia), 8(2), 285. https://doi.org/10.23887/jpiundiksha.v8i2.24162

Fatmawati, S. (2019). Efektivitas Forum Diskusi Pada E-Learning Berbasis Moodle Untuk Meningkatkan Partisipasi Belajar. Refleksi Edukatika: Jurnal Ilmiah Kependidikan, 9(2). https://doi.org/10.24176/re.v9i2.3379

Febliza, A., \& Okatariani, O. (2020). The Development of Online Learning Media by Using Moodle for General Chemistry Subject. Journal of Educational Science and Technology (EST), 6(1), 40. https://doi.org/10.26858/est.v6i1.12339

Garbin, C., Zhu, X., \& Marques, O. (2020). Dropout vs. batch normalization: an empirical study of their impact to deep learning. Multimedia Tools and Applications, 79(19-20), 2777-12815. https://doi.org/10.1007/s11042-019-08453-9

Gong, Y., Hu, X., \& Lai, C. (2018). Chinese as a second language teachers' cognition in teaching intercultural communicative competence. System, 78. https://doi.org/10.1016/j.system.2018.09.009

Hashemi, M., \& Aziznezhad, M. (2011). Computer Assisted Language Learning Freedom or Submission to Machines? Procedia - Social and Behavioral Sciences, 28. https://doi.org/10.1016/j.sbspro.2011.11.152

Herayanti, L., Habibi, H., \& Fuaddunazmi, M. (2017). Pengembangan Media Pembelajaran Berbasis Moodle pada Matakuliah Fisika Dasar. Jurnal Cakrawala Pendidikan, 36(2), 210-219. https://doi.org/10.21831/cp.v36i2.13077

Ho, Y.-Y. C. (2020). Communicative language teaching and English as a foreign language undergraduates' communicative competence in Tourism English. Journal of Hospitality, Leisure, Sport \& Tourism Education, 27. https://doi.org/10.1016/j.jhlste.2020.100271

Huseyin, Demirezen, M., \& Pourfeiz, J. (2015). Digital Device Ownership, Computer Literacy, And Attitudes Toward Foreign And Computer-Assisted Language Learning. Procedia - Social and Behavioral Sciences, 186. https://doi.org/10.1016/j.sbspro.2015.04.028

Khotimah, K., Widiati, U., Mustofa, M., \& Faruq Ubaidillah, M. (2019). Autonomous English learning: Teachers' and students' perceptions. Indonesian Journal of Applied Linguistics, 9(2), 371-381. https://doi.org/10.17509/ijal.v9i2.20234

Kristanto, A., Mustaji, \& Mariono, A. (2017). The development of instructional materials e-learning based on blended learning. Journal International Education Studies, 10(7), 10-17. https://doi.org/10.5539/ies.v10n7p10

Kyewski, E., \& Krämer, N. C. (2018). gamify or not to gamify? An experimental field study of the influence of badges on motivation, activity, and performance in an online learning course. Computers \& Education, 118, 25-37. https://doi.org/10.1016/j.compedu.2017.11.006

Li, J., Zhang, X., \& Hu, Z. (2018). The design and application of flip classroom teaching based on computer technology. International Journal of Emerging Technologies in Learning, 13(10), 95-107. https://doi.org/10.3991/ijet.v13i10.9453

Macaro, E., \& Tian, L. (2015). Exploring teachers' oral explanations of new English lexical items in a Chinese university: Comparisons with dictionary information. System, 52. https://doi.org/10.1016/j.system.2015.05.002

Mahmoudi, E., Samad, A. bt A., \& Razak, N. Z. B. A. (2012). Attitude and Students' Performance in Computer Assisted English Language Learning (CAELL) for Learning Vocabulary. Procedia - Social and Behavioral Sciences, 66. https://doi.org/10.1016/j.sbspro.2012.11.293

Mitra, N. K., Aung, H. H., Kumari, M., Perera, J., Sivakumar, A., Singh, A., \& Nadarajah, V. D. (2021). Improving the learning process in anatomy practical sessions of chiropractic program using e-learning tool. Translational Research in Anatomy, 23, 100100. https://doi.org/10.1016/j.tria.2020.100100

Mohd Kasim, N. N., \& Khalid, F. (2016). Choosing the Right Learning Management System (LMS) for the Higher Education Institution Context: A Systematic Review. International Journal of Emerging Technologies in Learning (IJET), 11(06), 55. https://doi.org/10.3991/ijet.v11i06.5644

Müller, A. M., Goh, C., Lim, L. Z., \& Gao, X. (2021). COVID-19 Emergency eLearning and Beyond: Experiences and Perspectives of University Educators. Education Sciences, 11(1), 19. https://doi.org/10.3390/educsci11010019

Nácher, M. J., Badenes-Ribera, L., Torrijos, C., Ballesteros, M. A., \& Cebadera, E. (2021). The effectiveness of the GoKoan e-learning platform in improving university students' academic performance. Studies in 
Educational Evaluation, 70. https://doi.org/10.1016/j.stueduc.2021.101026

Novrianti, N. (2014). Pengembangan Computer Based Testing (CBT) Sebagai Alternatif Teknik Penilaian Hasil Belajar. Lentera Pendidikan: Jurnal Ilmu Tarbiyah Dan Keguruan, 17(1). https://doi.org/10.24252/lp.2014v17n1a3

Nugroho, F., \& Iqbal Arrosyad, M. (2020). Moodle Multimedia Development in Web-based Integrative Thematic Learning for Class IV Elementary Students. Cendekiawan, 2(1), $49-63$. https://doi.org/10.35438/cendekiawan.v2i1.177

Prihandoko, Y., Slamet, S. Y., \& Winarno. (2017). Cognitive Moral Approach To Civics Education Material Development In The Elementary School. Jurnal Kependidikan, 1(2), 200-2013. https://doi.org/10.21831/jk.v1i2.15279

Ramkissoon, P., Belle, L. J., \& Bhurosy, T. (2020). Perceptions and experiences of students on the use of interactive online learning technologies in Mauritius. International Journal of Evaluation and Research in Education. https://doi.org/10.11591/ijere.v9i4.20692

Sadeghi, A., \& Sadeghi, A. (2012). The relevance of Mastery Learning (ML) in Teaching of English (Case Study of the University of Guilan, Iran). Creative Education, 3(1). https://doi.org/10.4236/ce.2012.31007

Sarfraz, S., Mansoor, Z., \& Tariq, R. (2015). Teachers' and Students' Perceptions of the Communicative Language Teaching Methodology in the CALL Environment: A Case Study. Procedia - Social and Behavioral Sciences, 199. https://doi.org/10.1016/j.sbspro.2015.07.604

Shetu, S. F., Rahman, M. M., Ahmed, A., Mahin, M. F., Akib, M. A. U., \& Saifuzzaman, M. (2021). Impactful e-learning framework: A new hybrid form of education. Current Research in Behavioral Sciences, 2. https://doi.org/10.1016/j.crbeha.2021.100038

Sirivedin, P., Soopunyo, W., Srisuantang, S., \& Wongsothorn, A. (2018). Effects of Facebook usage on English learning behavior of Thai English teachers. Kasetsart Journal of Social Sciences, 39(2). https://doi.org/10.1016/j.kjss.2018.03.007

Sokolova, E. Y., Golovacheva, E. A., \& Chernaya, A. A. (2018). Professionally-Oriented Communicative Language Teaching Approach by the Design of a Computer Assisted ESP Course: Analysis of Results. Procedia - Social and Behavioral Sciences, 215. https://doi.org/10.1016/j.sbspro.2015.11.619

Sorensen, E. (2013). Implementation and student perceptions of e-assessment in a Chemical Engineering module. European Journal of Engineering Education, 38(2), 172-185. https://doi.org/10.1080/03043797.2012.760533

Sprenger, D. A., \& Schwaninger, A. (2021). Technology acceptance of four digital learning technologies (classroom response system, classroom chat, e-lectures, and mobile virtual reality) after three months' usage. International Journal of Educational Technology in Higher Education, 18(1), 1-17. https://doi.org/10.1186/s41239-021-00243-4

Usmanova, N., Shindina, T., \& Basharina, A. (2015). Development and Assessment of Interactive Teaching Approach Impact on Communicative Competence of Bachelors of Economic Universities. Procedia Social and Behavioral Sciences, 214. https://doi.org/10.1016/j.sbspro.2015.11.701

Valverde-Berrocoso, Garrido-Arroyo, Burgos-Videla, \& Morales-Cevallos. (2020). Trends in Educational Research about e-Learning: A Systematic Literature Review (2009-2018). Sustainability, 12(12). https://doi.org/10.3390/su12125153

Wang, S., Jiao, H., Young, M. J., Brooks, T., \& Olson, J. (2018). Comparability of Computer-Based and Paperand-Pencil Testing in K-12 Reading Assessments: A Meta-Analysis of Testing Mode Effects. Educational and Psychological Measurement, 68(1). https://doi.org/10.1177/0013164407305592

Wei, L., Lin, H.-H., \& Litton, F. (2018). Communicative Language Teaching (CLT) in EFL Context in Asia. Asian Culture and History, 10(2). https://doi.org/10.5539/ach.v10n2p1

$\mathrm{Wu}$, T. T., \& Wu, Y. T. (2020). Applying project-based learning and SCAMPER teaching strategies in engineering education to explore the influence of creativity on cognition, personal motivation, and personality traits. Thinking Skills and Creativity, 35(January), 100631. https://doi.org/10.1016/j.tsc.2020.100631

Yafaei, Y. Al, \& Attamimi, R. (2019). Understanding Teachers' Integration of Moodle in EFL Classrooms: A Case Study. English Language Teaching, 12(4). https://doi.org/10.5539/elt.v12n4p1

Yilmaz, E., \& Korur, F. (2021). The Effects of an Online Teaching Material Integrated Methods on Students' Science Achievement, Attitude and Retention. International Journal of Technology in Education, 4(1). https://doi.org/10.46328/ijte.79

Zabolotniaia, M., Cheng, Z., Dorozhkin, E., \& Lyzhin, A. (2020). Use of the LMS Moodle for an Effective Implementation of an Innovative Policy in Higher Educational Institutions. International Journal of Emerging Technologies in Learning (IJET), 15(13), 172. https://doi.org/10.3991/ijet.v15i13.14945 